\title{
Article \\ A Comparative Study of the Effects of Platinum (II) Complexes on $\beta$-Amyloid Aggregation: Potential Neurodrug Applications
}

\author{
Sara La Manna ${ }^{1}{ }^{\circ}$, Daniele Florio ${ }^{1}$, Ilaria Iacobucci ${ }^{2}{ }^{\circ}$, Fabiana Napolitano ${ }^{3} \oplus$, Ilaria De Benedictis ${ }^{1}$,

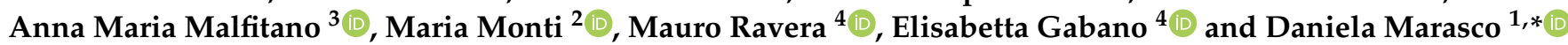 \\ 1 Department of Pharmacy, University of Naples "Federico II", 80131 Naples, Italy; \\ sara.lamanna@unina.it (S.L.M.); floriodaniele1@gmail.com (D.F.); ilariadebenedictis2308@gmail.com (I.D.B.) \\ 2 Department of Chemical Sciences, CEINGE Biotecnologie Avanzate S.c.a r.l., “University of Naples Federico \\ II", 80131 Naples, Italy; ilaria.iacobucci@unina.it (I.I.); montimar@unina.it (M.M.) \\ 3 Department of Translational Medical Science, University of Naples "Federico II", 80131 Naples, Italy; \\ fabiananapolitano94@gmail.com (F.N.); annamaria.malfitano@unina.it (A.M.M.) \\ 4 Department of Sciences and Technological Innovation (DiSIT), University of Piemonte Orientale \\ “A. Avogadro”, 15121 Alessandria, Italy; mauro.ravera@uniupo.it (M.R.); elisabetta.gabano@uniupo.it (E.G.) \\ * Correspondence: daniela.marasco@unina.it; Tel.: +39-081-2534512; Fax: +39-081-2534574
}

\section{check for} updates

Citation: Manna, S.L.; Florio, D.; Iacobucci, I.; Napolitano, F.; Benedictis, I.D.; Malfitano, A.M.; Monti, M.; Ravera, M.; Gabano, E.; Marasco, D. A Comparative Study of the Effects of Platinum (II) Complexes on $\beta$-Amyloid Aggregation: Potential Neurodrug Applications. Int. J. Mol. Sci. 2021, 22, 3015. https://doi.org/ $10.3390 /$ ijms22063015

Academic Editor: Viktor Brabec

Received: 20 February 2021

Accepted: 10 March 2021

Published: 16 March 2021

Publisher's Note: MDPI stays neutral with regard to jurisdictional claims in published maps and institutional affiliations.

Copyright: (c) 2021 by the authors. Licensee MDPI, Basel, Switzerland. This article is an open access article distributed under the terms and conditions of the Creative Commons Attribution (CC BY) license (https:// creativecommons.org/licenses/by/ $4.0 /)$.

\begin{abstract}
Herein the effects of three platinum complexes, namely ( $S P-4-2)-\left(2,2^{\prime}\right.$-bipyridine)dichlorido platinum(II), Pt-bpy, (SP-4-2)-dichlorido(1,10-phenanthroline) platinum(II), Pt-phen, and (SP-4-2)chlorido( $2,2^{\prime}: 6^{\prime}, 2^{\prime \prime}$-terpyridine)platinum(II) chloride, Pt-terpy, on the aggregation of an amyloid model system derived from the C-terminal domain of $A \beta$ peptide $\left(A \beta_{21-40}\right)$ were investigated. Thioflavin $\mathrm{T}$ (ThT) binding assays revealed the ability of $\mathrm{Pt}(\mathrm{II})$ compounds to repress amyloid aggregation in a dose-dependent way, whereas the ability of $A \beta_{21-40}$ peptide to interfere with ligand field of metal complexes was analyzed through UV-Vis absorption spectroscopy and electrospray ionization mass spectrometry. Spectroscopic data provided micromolar $\mathrm{EC}_{50}$ values and allowed to assess that the observed inhibition of amyloid aggregation is due to the formation of adducts between $\mathrm{A} \beta_{21-40}$ peptide and complexes upon the release of labile ligands as chloride and that they can explore different modes of coordination toward $A \beta_{21-40}$ with respect to the entire $A \beta_{1-40}$ polypeptide. In addition, conformational studies through circular dichroism (CD) spectroscopy suggested that $\mathrm{Pt}$ terpy induces soluble $\beta$-structures of monomeric $A \beta_{21-40}$, thus limiting self-recognition. Noticeably, Pt-terpy demonstrated the ability to reduce the cytotoxicity of amyloid peptide in human SH-SY5Y neuroblastoma cells. Presented data corroborate the hypothesis to enlarge the application field of already known metal-based agents to neurodegenerative diseases, as potential neurodrugs.
\end{abstract}

Keywords: amyloid aggregation; metallodrugs; platinum (II) compounds; anti-aggregation properties

\section{Introduction}

A $\beta$-amyloid peptides (1-40 and 1-42) form oligo- and multi-meric aggregates that evolve into fibrils recovered in the brains of patients affected by Alzheimer's disease (AD) [1]. Peptide sequences at early stages of aggregation, both as monomers and oligomers, are largely disordered and able to create coordination bonds with transition metal ions, that change the kinetics and mechanism of self-recognition [2]. Transition metal complexes are able to modulate/inhibit amyloids' aggregation and possibly their toxicity through different mechanisms [3]: (i) coordination chemistry, (ii) oxidative and (iii) proteolytic reactions [4] for peptide modifications. These processes depend on tunable features of complexes, including the oxidation state of the ion and the coordination geometry of the metal center $[5,6]$. In addition, $\beta$-amyloid peptides are involved in the homeostasis of several bio-active metal ions as copper(I, II) and zinc(II). Several studies outlined how the $\mathrm{A} \beta$ peptide/Cu interactions are mediated by the $\mathrm{N}$-terminal region of 
$\mathrm{A} \beta$-amyloid involving His ${ }^{6}, \mathrm{His}^{13}$, and $\mathrm{His}^{14}$ and that these interactions modulate the aggregation and toxicity profiles of the entire $\mathrm{A} \beta_{1-40}$ sequence [7]. In general, $\mathrm{Pt}(\mathrm{II})$ and $\mathrm{Ru}(\mathrm{III})$ [8] complexes are more stable and redox inert with respect to $\mathrm{Zn}-, \mathrm{Cu}-$, or Fe-based compounds, thus, they can have major chances of success to prevent toxic effects of $A \beta$ oligomerization in a coordinative mechanism and to serve as potential neurodrugs [9]. Many investigations reported on the ability of $\mathrm{Pt}(\mathrm{II})$ complexes to interfere with amyloid aggregation. Initial studies involved $\mathrm{Pt}(\mathrm{II})$ compounds bearing 1,10-phenanthroline (phen)-based bidentate ligands along with two monodentate ligands (e.g., chlorides), as an inhibitor of aggregation of $A \beta_{1-40}$ via the exchange of the latter ligands followed by the coordination to the imidazoles of His residues of the $\mathrm{N}$-terminal region of $\mathrm{A} \beta_{1-40}$ [10]. $\pi-\pi$ interactions between the phen moiety and aromatic Phe ${ }^{4}$, Tyr ${ }^{10}$ and $\mathrm{Phe}^{19}$ aid the formation of the $\left[\mathrm{Pt}^{\mathrm{II}}\right.$ (phen)-(A $\left.\left.\beta\right)\right]^{2+}$ adduct that suppressed aggregation and limited the neurotoxicity of $A \beta$ in mouse hippocampal tissue [10]. Other studies reported on the interaction of Pt-phen complexes not only with the entire $A \beta_{1-40}$ sequence but also with smaller regions of the N-terminal domain [11]: NMR, X-ray absorption spectroscopy (XAS), mass spectrometry (MS), and molecular modeling investigations [12] further confirmed that the planar hydrophobic phen ligand stabilized histidine-protein adducts [13]. In detail, the non-covalent interactions of phen with the protein, and the coordination to the $\mathrm{Pt}(\mathrm{II})$ center of two His, limited the coordination of $\mathrm{Cu}$ (II) and $\mathrm{Zn}$ (II) $[14,15]$. Similarly, other Pt-complexes containing planar hydrophobic ligands demonstrated the ability to interact with the first 28 residues of $A \beta$-amyloid, $A \beta_{1-28}$, exhibiting different binding modes between the $\mathrm{Pt}(\mathrm{II})$ center and the polypeptide chain [16,17]. An important application is related to the detection of amyloid fibrillation through the employment of self-assembled luminescent Pt(II) complexes [18,19]. Very recently, we carried out several studies focusing on the effects of several metallo-drugs on the aggregation of several peptide sequences assumed as amyloid models [20-25]. The fragment spanning 21-40 residues of the Cterminal domain of $A \beta_{1-40}\left(A \beta_{21-40}\right.$, Table 1) was tested with $\mathrm{Pd}(\mathrm{II})-, \mathrm{Pt}(\mathrm{II})-$ and $\mathrm{Au}(\mathrm{III})$ compounds featuring 2-(2'-pyridyl)benzimidazole [26], Pt(II) complexes with $\beta$-hydroxy dithiocinnamic esters [9] and $\mathrm{Ru}(\mathrm{II})$-based CO-releasing molecules featuring bidentate benzimidazole and terpyridine derivatives [27]. They all revealed able to modulate selfassembly of different amyloid sequences employing coordination or oxidative mechanisms. Herein we investigated the interaction between the almost unexplored C-terminal fragment $\mathrm{A} \beta_{21-40}$, with a small series of $\mathrm{Pt}(\mathrm{II})$ compounds that were already demonstrated the ability to bind to the entire $\beta$-amyloid polypeptide [6]. The selected complexes were: (SP4-2)-(2,2'-ridine)dichloridoplatinum(II), Pt-bpy, (SP-4-2)-dichlorido(1,10-phenanthroline) platinum(II), Pt-phen, and (SP-4-2)-chlorido(2,2':6',"'-terpyridine)platinum(II) chloride, Pt-terpy) (Figure 1). Moreover, in order to assess the specificity of the observed results, we also investigated the potential effects of the $\mathrm{Pt}(\mathrm{II})$ complexes on a mutated version of $\mathrm{A} \beta_{21-40}$, namely mutA $\beta_{21-40}$ (Table 1 ), bearing the point mutation $\mathrm{G}^{37} / \mathrm{D}$ that was reported to suppress amyloid aggregation of the entire $A \beta_{1-42}$ [28].

Table 1. Peptide sequences analyzed in this study.

\begin{tabular}{cc}
\hline Peptide & Sequence \\
\hline $\mathrm{A} \beta_{21-40}$ & AEDVGSNKGAIIGLMVGGVV \\
mutA $\beta_{21-40}$ & AEDVGSNKGAIIGLMVDGVV \\
\hline
\end{tabular}


<smiles></smiles>

Pt-bpy<smiles>Cl[PH]1(Cl)c2ccc3c4c2N1C=CC=C4C=C3</smiles>

Pt-phen<smiles></smiles>

Pt-terpy

Figure 1. Structure of the Pt(II) complexes investigated in the present work (bpy $=2,2^{\prime}$-bipyridine, phen $=1,10$-phenanthroline, terpy $=2,2^{\prime}: 6^{\prime}, 2^{\prime \prime}$-terpyridine).

\section{Results}

\subsection{Effects of Pt Complexes on Thioflavin $T$ (ThT) Aassay of $A \beta_{21-40}$}

The ability of $\mathrm{Pt}$ complexes to affect the aggregation process of $\mathrm{A} \beta_{21-40}$ was monitored through the analysis, over time, of Thioflavin T (ThT) fluorescence emission, reported in Figure 2A. Two molar ratios for peptide: metal complexes were possible for Pt-terpy (i.e., 1:1 and 1:5), whereas Pt-phen and Pt-bpy resulted not soluble at the 1:5 ratio $([\mathrm{Pt}]=500 \mu \mathrm{M})$. The starting value of fluorescence different from 0 is ascribable to an immediate partial oligomerization during sample preparation, that however requires more time $(\sim 5 \mathrm{~h})$ to reach saturated ThT signal, as already observed [9,29]. Over time, $A \beta_{21-40}$ alone reached a saturated signal after $6 \mathrm{~h}$ of stirring, while mutA $\beta_{21-40}$ is not able to aggregate for $20 \mathrm{~h}$, as expected. At 1:1 ratio, $A \beta_{21-40}$ : Pt complexes, the effects of metal compounds are clearly suppressive of the self-assembly process even at initial times of aggregation. This is more evident for Pt-terpy and Pt-bpy complexes, while almost negligible for Pt-phen. A complete inhibition of the aggregation is displayed by 1:5 ratio of Pt-terpy that provides a signal similar to mutA $\beta_{21-40}$, for the entire duration of the analysis.

(A)

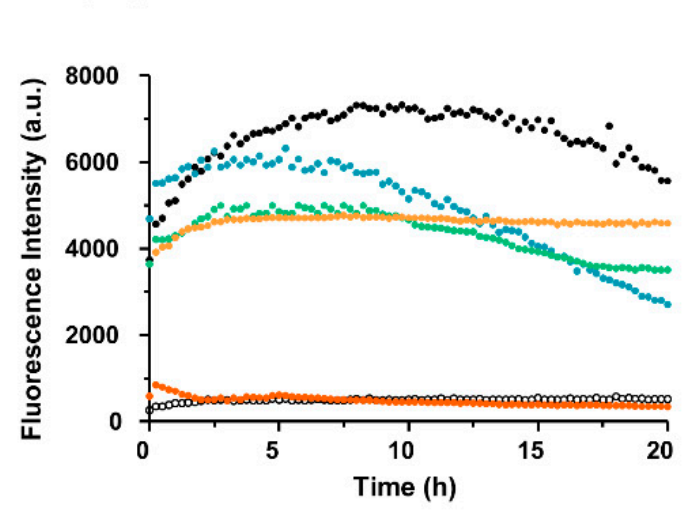

(B)

- $A \beta_{21-40}$ alone

- mutA $\beta_{21-40}$ alone

- $\mathrm{A} \beta_{21-40}+$ Pt-phen_1:1

- $A \beta_{21-40}+$ Pt-bpy_1:1

$A \beta_{21-40}+$ Pt-terpy_1:1

$A \beta_{21-40}+$ Pt-terpy_1:5

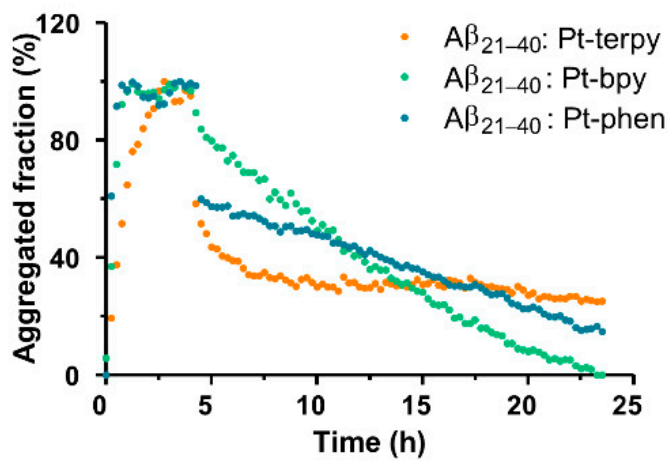

Figure 2. Time course of ThT fluorescence emission intensity of $A \beta_{21-40}$ peptides alone and upon the addition of Pt-phen, Pt-bpy, and Pt-terpy at (A) $\mathrm{t}=0$, at the indicated molar ratios, and (B) after $5 \mathrm{~h}$, time of addition is indicated with an arrow, at $1: 1$ ratio.

In addition, we investigated if $\mathrm{Pt}(\mathrm{II})$-complexes were able not only to inhibit $\mathrm{A} \beta_{21-40}$ aggregation but also to modulate its disaggregation. Hence the ThT-intensity profiles versus time upon the addition of complexes at 1:1 ratio, on pre-formed soluble aggregates are reported in Figure 2B. Interestingly, we observed a decrease of ThT fluorescence intensity upon the addition of all three complexes with different times of decrease. Once again, $\mathrm{Pt}$ terpy proved to be the most effective since it caused an immediate decrease of aggregated fractions greater than $60 \%$ while for $\mathrm{Pt}$-phen the time of decrease was similar, but a 
reduction of the fraction was of $\sim 40 \%$. Conversely, the disaggregation caused by Pt-bpy was slower and only after $15 \mathrm{~h}$ provided effects comparable to those exhibited by the other two metal complexes.

\subsection{Analysis of the Adducts between $A \beta_{21-40}$ and Pt(II) Complexes through Mass Spectrometry}

Samples of $A \beta_{21-40}$ alone and incubated with the Pt compounds were analyzed at two different times ( 0 and $24 \mathrm{~h}$ ) by electrospray ionization mass spectrometry (ESI-MS) [30]. As reported in Figure 3, ESI-MS spectra recorded at $24 \mathrm{~h}$, showed that all the three Pt complexes are able to bind one chain of the $A \beta_{21-40}$, and all the species detected at the longest time were already present at $t=0$ (Table 2). By a detailed inspection of the MS spectra of $A \beta_{21-40}$ with Pt-phen and Pt-bpy (Figure 3B-C), two double-charged ions were present: one at higher $\mathrm{m} / \mathrm{z}$ values (Pt-phen $m / z=1168.52 \mathrm{Da}$; Pt-bpy $m / z=1156.50 \mathrm{Da}$ ) and a second peak at lower $\mathrm{m} / \mathrm{z}$ values (Pt-phen $m / z=1150.52 \mathrm{Da}$; Pt-bpy $m / z=1138.02 \mathrm{Da}$ ), deriving by the loss of one and two chloride ions, respectively. These latter peaks increased over time, as already observed in similar studies [27]. In addition, the species missing two chloride ions are flanked by the presence of an adduct deriving from the substitution of a chloride with an acetate ion, present in the buffer (Pt-phen $m / z=1180.04 \mathrm{Da}$; Pt-bpy $m / z=1168.05 \mathrm{Da}$ ). A $\beta_{21-40}$ formed an adduct with one molecule of Pt-terpy (Figure 3D), losing the only chloride present, as demonstrated by the presence of the double charged ion at $m / z 1176.57 \mathrm{Da}$. Moreover, in the ESI-MS acquiring conditions, the isolated $\mathrm{A} \beta_{21-40}$ peptide provided an in-source fragmentation phenomena, generating $b$ series fragments (Figure $3 \mathrm{~A}$ ), as previously reported [26]. The fragmentation of free $A \beta_{21-40}$ peptide persisted also in the presence of Pt-phen (Figure 3B) and Pt-terpy (Figure 3D), since a large amount of peptide was unbound. Conversely, in the presence of Pt-bpy no free peptide fragmentation was detectable (Figure 3C), since the largest part of $\mathrm{A} \beta_{21-40}$ was bound to the Pt-compound. However, differently from other complexes, $\mathrm{A} \beta_{21-40} / \mathrm{Pt}$-bpy is the unique adduct to provide fragmentation, as confirmed by mono- and double-charged species of $b_{20} C$-terminal fragment evidenced in the ESI-MS spectrum. As a control experiment, mutA $\beta_{21-40}$ alone and in presence of Pt-terpy was also studied, and no peaks attributable to the adduct formed by the peptide and the metal complex were evidenced (see Figure S1, Supplementary Material). MS data demonstrated that all Pt-compounds bind $\mathrm{A} \beta_{21-40}$ with 1:1 stoichiometry and that the adduct with Pt-bpy resulted more abundant with respect to the others, as demonstrated by the dominant species in the spectrum associated with the complex and its $b_{19}$ fragment. 


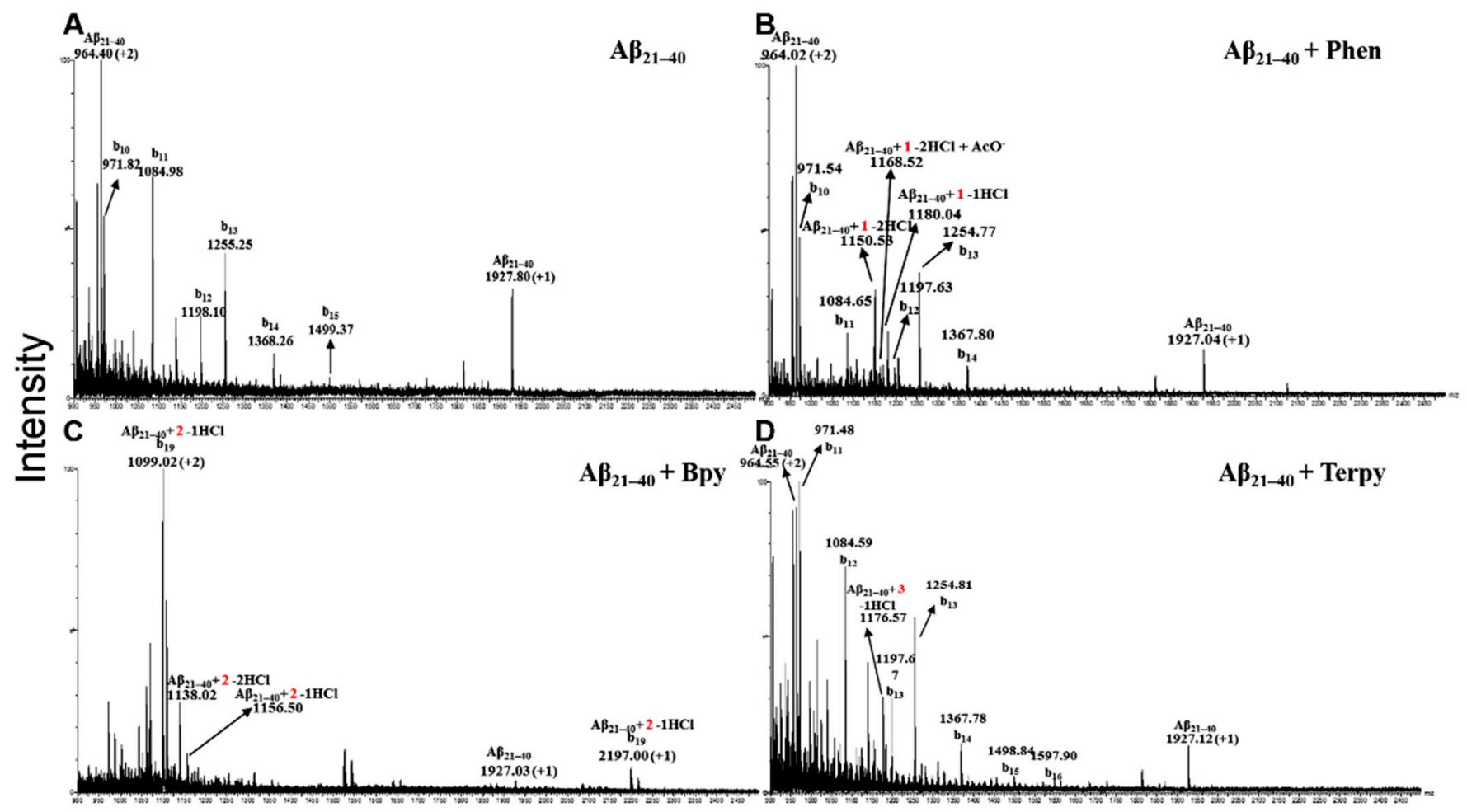

$\mathrm{m} / \mathrm{z}$

Figure 3. ESI-MS spectra of $A \beta_{21-40}$ peptide at $24 \mathrm{~h}$ of incubation with Pt-derivates. (A) Isolated $\mathrm{A} \beta_{21-40} \cdot(\mathbf{B}) \mathrm{A} \beta_{21-40}+$ Pt-phen. (C) $\mathrm{A} \beta_{21-40}+$ Pt-bpy. (D) $\mathrm{A} \beta_{21-40}+$ Pt-terpy. The presence of the Pt moieties in the ions is indicated with 1, 2 and 3 , respectively. Fragmentation ions are also indicated.

Table 2. Summary of main ion species occurring in the ESI-MS spectra of $A \beta_{21-40}$ with the three Pt-derivates, at 0 and $24 \mathrm{~h}$ of incubation. Each detected adduct is reported with the corresponding experimental $\mathrm{m} / \mathrm{z}$ values, the charge state, the calculated and theoretical monoisotopic molecular weight.

\begin{tabular}{|c|c|c|c|c|c|}
\hline $\begin{array}{c}\text { Pt- } \\
\text { Derivate }\end{array}$ & Time & $\begin{array}{l}\text { Experimental } m / z, \\
\text { (Charge State) }\end{array}$ & $\begin{array}{c}\text { Experimental } \\
\text { Monoisotopic } \\
\text { Mass (Da) }\end{array}$ & $\begin{array}{l}\text { Theoretical } \\
\text { Monoisotopic } \\
\text { Mass (Da) }\end{array}$ & Pt(II)-Peptide Complexes \\
\hline \multirow{6}{*}{ Pt-phen } & \multirow{3}{*}{$0 \mathrm{~h}$} & $1150.52(+2)$ & 2299.06 & 2299.29 & $\mathrm{~A} \beta_{21-40}+1$ Pt-phen $-2 \mathrm{HCl}$ \\
\hline & & $1180.04(+2)$ & 2358.07 & 2358.29 & $\mathrm{~A} \beta_{21-40}+1 \mathrm{Pt}$-phen $-2 \mathrm{HCl}+\mathrm{AcO}^{-}$ \\
\hline & & $1168.52(+2)$ & 2334.18 & 2335.74 & $\mathrm{~A} \beta_{21-40}+1$ Pt-phen $-1 \mathrm{HCl}$ \\
\hline & \multirow{3}{*}{$24 \mathrm{~h}$} & $1150.53(+2)$ & 2299.06 & 2299.29 & $\mathrm{~A} \beta_{21-40}+1$ Pt-phen $-2 \mathrm{HCl}$ \\
\hline & & $1180.04(+2)$ & 2358.07 & 2358.29 & $\mathrm{~A} \beta_{21-40}+1$ Pt-phen-2HCl$+\mathrm{AcO}^{-}$ \\
\hline & & $1168.50(+2)$ & 2335.00 & 2335.74 & $\mathrm{~A} \beta_{21-40}+1 \mathrm{Pt}-$ phen $-1 \mathrm{HCl}$ \\
\hline \multirow{5}{*}{ Pt-bpy } & \multirow{3}{*}{$0 \mathrm{~h}$} & $1138.02(+2)$ & 2274.04 & 2275.27 & $\mathrm{~A} \beta_{21-40}+1 \mathrm{Pt}-\mathrm{bpy}-2 \mathrm{HCl}$ \\
\hline & & $1168.05(+2)$ & 2234.10 & 2334.27 & $\mathrm{~A} \beta_{21-40}+1 \mathrm{Pt}-\mathrm{bpy}-2 \mathrm{HCl}+\mathrm{AcO}^{-}$ \\
\hline & & $1156.50(+2)$ & 2311.00 & 2311.72 & $\mathrm{~A} \beta_{21-40}+1 \mathrm{Pt}-\mathrm{bpy}-1 \mathrm{HCl}$ \\
\hline & \multirow{2}{*}{$24 \mathrm{~h}$} & $1138.02(+2)$ & 2274.04 & 2275.27 & $\mathrm{~A} \beta_{21-40}+1 \mathrm{Pt}-\mathrm{bpy}-2 \mathrm{HCl}$ \\
\hline & & $1156.50(+2)$ & 2310.00 & 2311.72 & $\mathrm{~A} \beta_{21-40}+1$ Pt-bpy $-1 \mathrm{HCl}$ \\
\hline \multirow{2}{*}{ Pt-terpy } & $0 \mathrm{~h}$ & $1176.56(+2)$ & 2351.14 & 2353.35 & $\mathrm{~A} \beta_{21-40}+1 \mathrm{Pt}$-terpy $-1 \mathrm{HCl}$ \\
\hline & $24 \mathrm{~h}$ & $1176.57(+2)$ & 2351.14 & 2353.35 & $\mathrm{~A} \beta_{21-40}+1$ Pt-terpy $-1 \mathrm{HCl}$ \\
\hline
\end{tabular}

\subsection{Changes of Absorption Spectral Features of Pt(II)-Complexes Caused by $A \beta_{21-40}$}

$\mathrm{UV} /$ Vis absorption spectroscopy was employed to detect potential variations of the ligand fields of investigated $\mathrm{Pt}$ (II) complexes introduced by the presence of amyloid peptide. The spectra of the $\mathrm{Pt}(\mathrm{II})$ complexes in the $200-400 \mathrm{~nm}$ region are characterized by the presence of more or less resolved or evident absorptions, which are combinations of internal $\pi \rightarrow \pi^{*}$ 
transitions of the ligand and metal-to-ligand charge transfer transitions [31-33]. As reported in Figure 4, the enhancement of absorbances upon increasing amounts of $A \beta_{21-40}$ for all three investigated $\mathrm{Pt}(\mathrm{II})$ complexes clearly suggests a substitution of ligands around metal ion from coordinating residues deriving from peptide side chains.
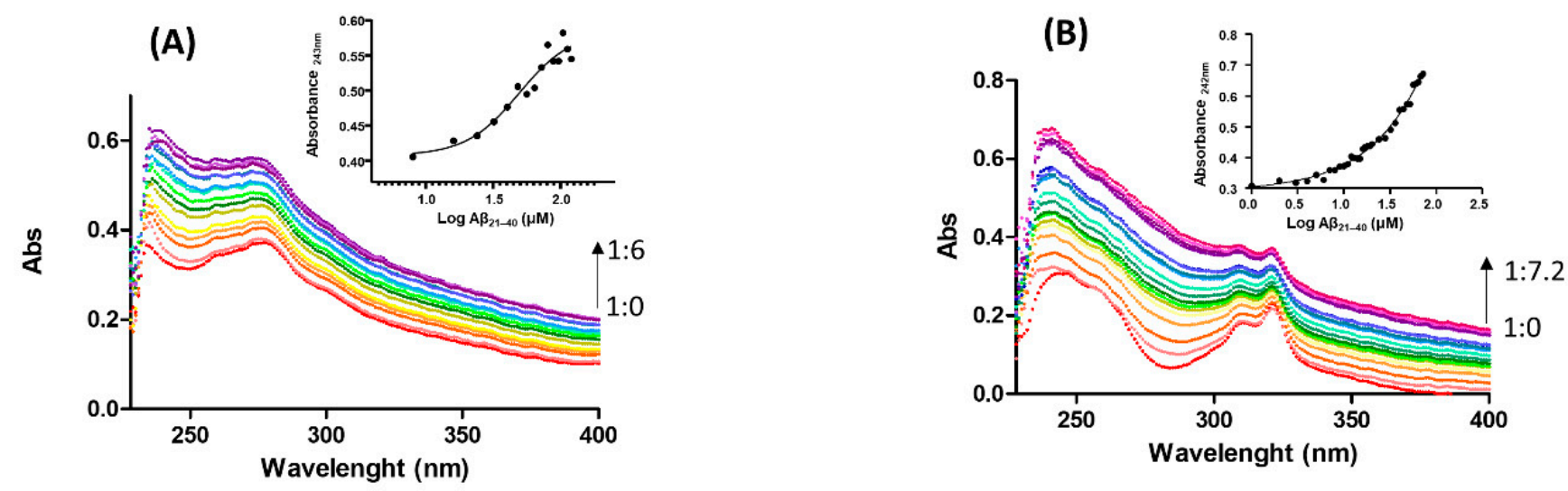

(C)

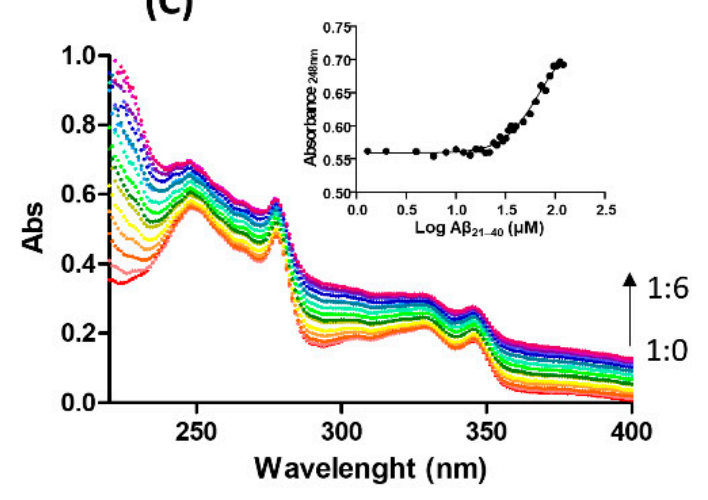

Figure 4. Absorption spectra of (A) Pt-phen, (B) Pt-bpy, (C) Pt-terpy upon the addition of increasing amount of A $\beta_{2-40}$. Arrow indicates ratio variation between complex and peptide. As insets UV intensities at indicated wavelengths versus Log concentration of $\mathrm{A} \beta_{21-40}$ are reported.

For Pt-phen and Pt-terpy (Figure 4A,C), the titration with $A \beta_{21-40}$ reached saturated values, providing an estimation of $\mathrm{EC}_{50}$ (half-maximal effective concentration) of $49 \pm 20 \mu \mathrm{M}$ (inset of Figure 4A) for Pt-phen and $68 \pm 14 \mu \mathrm{M}$ for Pt-terpy (inset of Figure 4C), respectively. On the contrary, Pt-bpy did not provide saturation even if a greater ratio (7.2:1, peptide: complex) was reached with respect to the other two complexes (6:1). To ensure that the increase of absorbance is not due to a dilution effect, similar assays, at the same concentration of the metal complexes were carried out by adding the same volumes of solvent as in the titration. As shown in Figure S2, slight intensity variations go in the opposite direction (decrease of signal) upon dilution, that cannot interfere with observed results of titration.

\subsection{Soluble Pt-Terpy Complex Stabilizes the $\beta$-Structure of $A \beta_{21-40}$}

To gain insights into the potential effects of Pt-complexes on the $\mathrm{A} \beta_{21-40}$ conformation, circular dichroism $(C D)$ investigations were carried out. Often the poor water solubility of metal-complexes requires handling with only freshly prepared samples greatly hampering the long time of analysis, in our case, since Pt-terpy revealed as the most potent inhibitor of ThT fluorescence and resulted soluble in aqueous solution, samples containing $\mathrm{A} \beta_{21-40} / \mathrm{Pt}$ terpy adducts were analyzed in long interval times (up to $3 \mathrm{~d}$ ). The overlays of $\mathrm{CD}$ spectra of $A \beta_{21-40}$ alone and $A \beta_{21-40}+$ Pt-terpy at 1:1 and 1:5 ratios are reported in Figure 5 . For $A \beta_{21-40}$, the $C D$ spectrum of a freshly prepared sample suggests the co-existence of random and $\beta$-structures (Figure 5A, red line), as confirmed by the deconvolution of the 
spectra (see Table S1 Supplementary Material) where their percentages are 23.4 and $55 \%$, respectively. Deconvolution at $\mathrm{t}=0$ estimates secondary structure contents in completely soluble conditions. In the following $20 \mathrm{~h}$ (yellow line) the conformation evolves toward a more defined $\beta$-structure, that remains prevalent, even if, from this time, a progressive reduction of Cotton effect is observable due to an aggregation/precipitation phenomenon. This behavior persists till $67 \mathrm{~h}$ when CD signal is almost null (blue line). For $\mathrm{A} \beta_{21-40}+$ Pt-terpy at 1:1 ratio, the $t=0 \mathrm{~h} C D$ profile (Figure 5B, red line) suggest a stabilization of $\beta$-structure with respect to that observed in absence of Pt complex ( $34.1 \%$ for $\beta$ and $44.9 \%$ for random. Table S1), as already reported for similar complexes to $A \beta_{21-40}[9]$ and the coordination of $\mathrm{Zn}(\mathrm{II})$ to $\mathrm{A} \beta_{1-40}$ [34]. This conformation seems to be reinforced after $4 \mathrm{~h}$ (orange line) and maintained in the following hours. After $20 \mathrm{~h}$ (yellow line) the decrease of Cotton effect is downsized with respect to $A \beta_{21-40}$ alone since even at $67 \mathrm{~h} \mathrm{CD}$ signal is meaningful (blue line). A similar behavior was exhibited by $\mathrm{A} \beta_{21-40}+$ Pt-terpy at 1:5 ratio (Figure 5C): in this case, the stabilization of $\beta$-structure by the Pt complex, at early stages of analysis, is more evident with respect to $1: 1$ sample, since the spectrum at $t=0 \mathrm{~h}$ (red line) is almost superimposable to that at $\mathrm{t}=4 \mathrm{~h}$ (orange line).

(A)

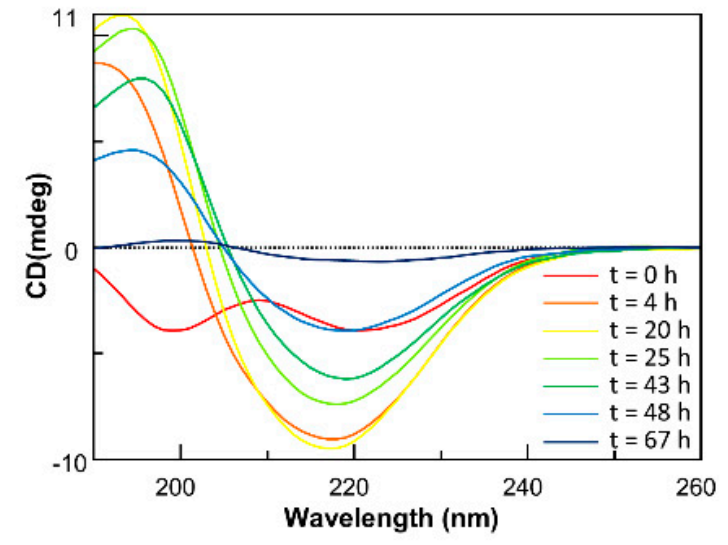

(B)

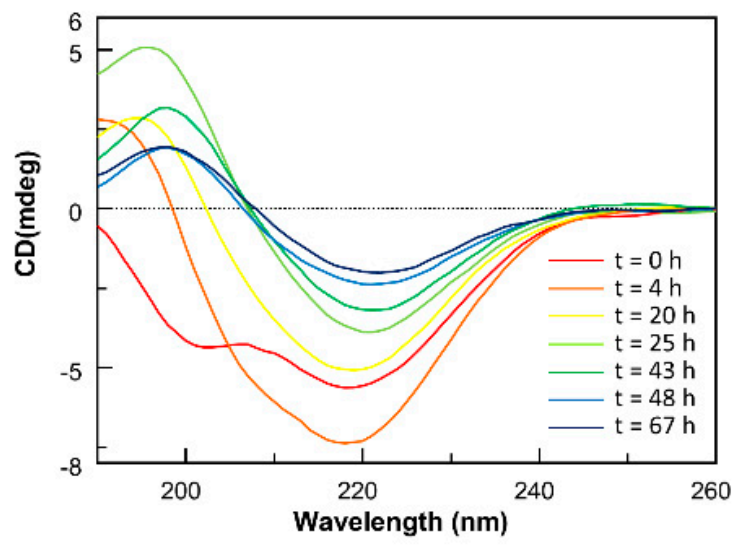

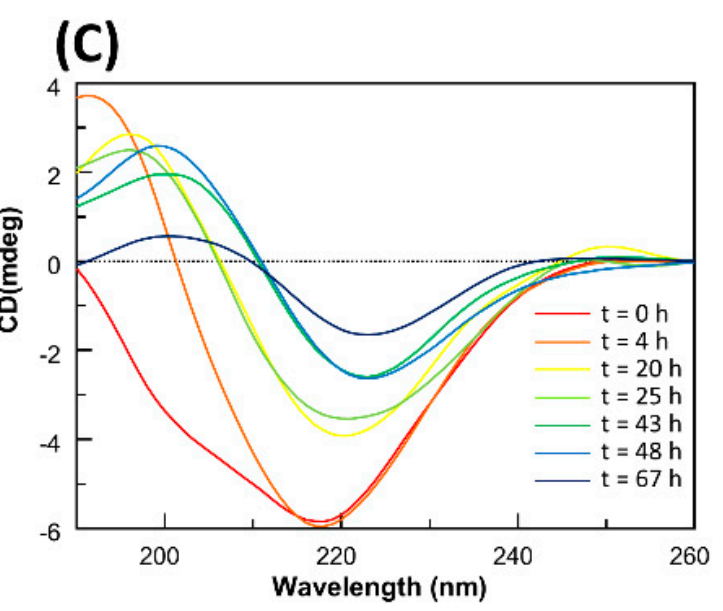

Figure 5. Overlay of CD spectra of $A \beta_{21-40}(\mathbf{A})$ alone, incubated with Pt-terpy at (B) 1:1 and (C) 1:5 peptide: Pt(II) compound molar ratio.

As control experiments, the time course of the $C D$ with mut $A \beta_{21-40}$ peptide in presence and absence of Pt-terpy was evaluated. Differently from the profile of the wild-type sequence, in the overlay of CD spectra of the mutant peptide (Figure S3A) the absence of conformational transition through $\beta$-structures for all time of analysis, confirmed the inability to form amyloid assemblies by these sequences, corroborating ThT assay results. 
Nevertheless, the reduction of Cotton effect starting from $\sim 40 \mathrm{~h}$ is likely due to an amorphous aggregation propensity of the entire sequence. Similarly to wild-type sequence, the addition of $\mathrm{Pt}(\mathrm{II})$ terpy provided a stabilization of $\beta$-structure (Figure S3B).

\subsection{Soluble Pt-Terpy Complex Inhibits Cytotoxic Effects of A $\beta_{21-40}$ Peptide in SH-SY5Y Cells}

The ability of the Pt-terpy complex to reduce the toxicity of $A \beta_{21-40}$ was assessed using human SH-SY5Y neuroblastoma cells. Cell proliferation was evaluated after treating cells with the peptide alone or in the presence of Pt-terpy, at 1:5 ratio peptide: complex (Figure 6) that represents the limit of water solubility for metal compound. Pt-terpy demonstrated the efficiency to interfere with the aggregation of $A \beta_{21-40}$ (Figure 2). With respect to cells alone (that present, as expected, comparable proliferation), $\mathrm{A} \beta_{21-40}$ peptide caused a significant reduction of cell proliferation even at $\mathrm{t}=0$ of analysis: this can be likely due to both partial aggregated state of prepared sample (as also observed for starting values of ThT analysis, Figure 2A) and to a long time of cellular analysis. However, the highest reduction ( $40 \%)$ was exhibited at $2 \mathrm{~h}$ while, after $24 \mathrm{~h}$, it demonstrated limited effects on proliferation that increased at $\sim 75 \%$. This behavior was already observed for similar amyloid systems in the transition from initial toxic small and soluble aggregates toward later, larger, and less toxic assemblies [35]. On the other hand, the adduct $A \beta_{21-40}+$ Pt-terpy exhibited a quite different behavior, indeed a rescue of cell proliferation with respect to $A \beta_{21-40}$ was observed that clearly indicates the inhibition of $A \beta_{21-40}$ toxic effects [36].

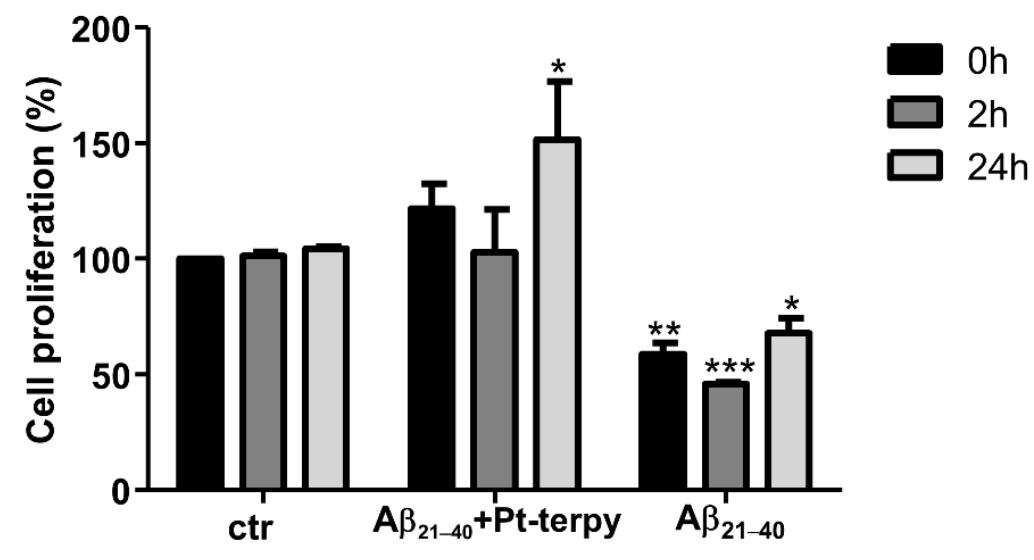

Figure 6. Cell proliferation assays in SH-SY5Y cells treated with $A \beta_{21-40}$ alone and $A \beta_{21-40}$ : Ptterpy at 1:5 peptide to metal compounds molar ratio at three different times. Statistical analysis was calculated by GraphPad Prism 7 by two-way Anova with Dunnett's multiple comparison test (* $p \leq 0.05,{ }^{* *} p \leq 0.005$ and ${ }^{* * *} p \leq 0.0005$ vs. basal (at corresponding time)).

\section{Discussion}

Metal-based compounds present exclusive mechanisms of action (MOAs) that are finely regulated by properties exerted by different (i) kinetics, (ii) coordination geometries, (iii) redox states (iv) and hydrophobicity of ligands [6]. These features could provide unexplored therapeutic approaches employing metal complexes as drugs [11]. Our recent investigations outlined the versatility of metal-based anticancer drugs to be applied in other fields of drug discovery as neurodegenerative diseases: in them, short peptide sequences demonstrated suited model systems of grater related proteins to investigated different MOAs of Pt-, Ru- and $\mathrm{Au}$ - complexes as effectors of amyloid aggregation $[9,26,27]$. Herein the modulation of self-assembly of the $C$-terminal region of $\beta$-amyloid, $A \beta_{21-40}$, by several $\mathrm{Pt}(\mathrm{II})$ derivatives, containing different ligands, was investigated. Time-course analysis of ThT fluorescence indicates a clear reduction of the aggregative process mostly for Pt-terpy and Pt-bpy complexes, a 1:1 ratio. Noticeably this reduction translates both in inhibitory and disaggregating effects on pre-formed soluble oligomers. ESI-MS spectrometry and $\mathrm{UV} /$ Vis absorption spectroscopy experiments indicate that the modulation of amyloid 
aggregation depends on the formation of adducts between metal-compounds and the A $\beta_{21-40}$ peptide, a 1:1 stoichiometry. By comparing present and previous data $[9,26]$ $\mathrm{A} \beta_{21-40}$ fragment was very sensitive to the action of $\mathrm{Pt}(\mathrm{II})$-complexes and in this study, the coordination of side chains of amino acids of the peptide to the $\mathrm{Pt}(\mathrm{II})$ ion occurs upon the release of the two or one coordinated $\mathrm{Cl}$ ions. Another important result of the present study relies on the druggability of the fragment $21-40$ of $\beta$-amyloid: indeed, the same metal complexes investigated on full-length or $\mathrm{N}$-terminal regions of $\mathrm{A} \beta_{1-40 / 42}$ sequences, revealed able to target a C-terminal region of amyloid polypeptide, even if with a different MOA excluding the His-coordination to $\mathrm{Pt}(\mathrm{II})$ ion. Interestingly, the presence of Pt-terpy was able to inhibit the $\mathrm{A} \beta_{21-40}$ toxicity in human SH-SY5Y neuroblastoma cells restoring cell proliferation. This is an important indication of the inhibition of $A \beta_{21-40}$ toxic effects on living cells and not in simpler model systems. In conclusion, we have presented several promising results of anti-aggregation properties of $\mathrm{Pt}(\mathrm{II})$ complexes, employing a coordinative mechanism, and their potential therapeutic application in neurodegenerative diseases.

\section{Materials and Methods}

\subsection{Peptide Synthesis}

Wild-type and mutA $\beta_{21-40}$ peptides were synthesized as already reported $[9,26,27]$. The sequences are reported in Table 1 , after purification they were lyophilized and treated with HFIP to ensure a monomeric state and then stored at $-20{ }^{\circ} \mathrm{C}$ until use.

\subsection{Synthesis of the Complexes}

Pt-terpy was obtained by using the traditional reaction between (SP-4-2)-dichlorido(cyc loocta-1,5-diene)platinum(II), [ $\mathrm{PtCl}_{2}$ (cod)], and 2,2': $6^{\prime}, 2^{\prime \prime}$-terpyridine [37]. Pt-bpy was synthesized by a microwave-assisted reaction between $\mathrm{K}_{2}\left[\mathrm{PtCl}_{4}\right]$ and 2,2'-bipyridine [38]. Pt-phen was synthesized adapting the same procedure employed for Pt-bpy. The chemicals used for the synthesis were obtained from common commercial sources, used as received and without further purification. Microwave irradiation was performed by using a CEM Discover ${ }^{\circledR}$ SP System equipped (CEM corporation, England) with a focused single-mode and self-tuning cavity, an air-cooling system, and an automated power control based on temperature feedback, supplying power in $1 \mathrm{~W}$ increments from 0 to $300 \mathrm{~W}$. The purity of all the compounds was assessed by elemental analysis on an EA3000 CHN Elemental Analyzer (EuroVector, Milano, Italy). Electrospray ionization mass spectra (ESI-MS) were obtained using a Waters HPLC-MS instrument equipped with a 3100 mass detector (Agilent, Milan, Italy), setting the source and desolvation temperatures at $150^{\circ} \mathrm{C}$ and $250^{\circ} \mathrm{C}$, respectively, and using nitrogen both as a drying and as a nebulizing gas. The cone and the capillary voltages were usually $30 \mathrm{~V}$ or $20 \mathrm{~V}$ and $2.70 \mathrm{kV}$, respectively. Quasi-molecular ion peaks $[\mathrm{M}+\mathrm{H}]^{+}$or $[\mathrm{M}+\mathrm{Na}]^{+}$were assigned on the basis of the $m / z$ values and of the simulated isotope distribution patterns. The NMR spectra were measured on an NMR-Bruker Avance III spectrometer (Bruker, Milan, Italy) operating at $500 \mathrm{MHz}\left({ }^{1} \mathrm{H}\right), 125.7 \mathrm{MHz}\left({ }^{13} \mathrm{C}\right)$, and 107.2 MHz ( ${ }^{195} \mathrm{Pt}$ with a spectral window of $2000 \mathrm{ppm}$ ), respectively. ${ }^{1} \mathrm{H}$ and ${ }^{13} \mathrm{C}$ NMR chemical shifts were reported in parts per million (ppm) referenced to solvent resonances. ${ }^{195} \mathrm{Pt}$ NMR spectra were recorded using a solution of $\mathrm{K}_{2} \mathrm{PtCl}_{4}$ in saturated aqueous $\mathrm{KCl}$ as the external reference. The shift for $\mathrm{K}_{2} \mathrm{PtCl}_{4}$ was adjusted to $-1628 \mathrm{ppm}$ from $\mathrm{Na}_{2} \mathrm{PtCl}_{6}$ $(\delta=0 \mathrm{ppm})$.

Synthesis of (SP-4-2)-dichlorido(1,10-phenanthroline)platinum(II), Pt-phen

In a $10-\mathrm{mL}$ microwave vessel to a solution of $\mathrm{K}_{2}\left[\mathrm{PtCl}_{4}\right](30 \mathrm{mg})$ in water $(3 \mathrm{~mL})$, 1 eq of 1,10-phenantroline in ethanol $(1 \mathrm{~mL})$ was added. After capping it, the vessel was introduced into the microwave oven and heated to $60^{\circ} \mathrm{C}$ over a 5-min ramp period and then kept at this temperature for $15 \mathrm{~min}$ under stirring (power $10 \mathrm{~W}$ ). After cooling it to room temperature, the vessel was removed from the cavity and further cooled to $0{ }^{\circ} \mathrm{C}$ to increase the amount of yellow precipitate, which was then separated by centrifugation and 
washed with water, methanol, and diethyl ether. Yield: 51\%. ESI-MS (positive ion mode): found $469 \mathrm{~m} / z$; calcd. for $\mathrm{C}_{12} \mathrm{H}_{8} \mathrm{Cl}_{2} \mathrm{~N}_{2} \mathrm{NaPt}[\mathrm{M}+\mathrm{Na}]^{+} 469 \mathrm{~m} / z$. ${ }^{1} \mathrm{H}-\mathrm{NMR}\left(\mathrm{DMF}-\mathrm{d}_{7}\right) \delta: 8.26$ $\left(\mathrm{dd}, 2 \mathrm{H}, \mathrm{H} 3\right.$ and $\left.\mathrm{H} 8, J^{3}=8.2 \mathrm{~Hz}, J^{3}=5.4 \mathrm{~Hz}\right), 8.38(\mathrm{~s}, 2 \mathrm{H}, \mathrm{H} 5$ and H6), $9.14(\mathrm{dd}, 2 \mathrm{H}, \mathrm{H} 4$ and $\left.\mathrm{H} 7, J^{3}=8.2 \mathrm{~Hz}, J^{4}=1.1 \mathrm{~Hz}\right), 9.86\left(\mathrm{dd}, 2 \mathrm{H}, \mathrm{H} 2\right.$ and $\left.9, J^{3}=5.4 \mathrm{~Hz}, J^{4}=1.1 \mathrm{~Hz}\right) \mathrm{ppm}$. ${ }^{13}$ C-NMR (DMF-d $)$ ) $8: 126.4$ (C3 and C8), 128.2 (C5 and C6), 131.4 (C4a and C6a), 139.8 (C4 and C7), 148.4 (C1a and C10a), 149.4 (C2 and C9) ppm. ${ }^{195} \mathrm{Pt}-\mathrm{NMR}\left(\mathrm{DMF}-\mathrm{d}_{7}\right) \delta:-2322$ ppm. Elemental analysis calcd. for $\mathrm{C}_{12} \mathrm{H}_{8} \mathrm{Cl}_{2} \mathrm{~N}_{2} \mathrm{Pt} \mathrm{C}, 32.30 \% ; \mathrm{H}, 1.81 \% ; \mathrm{N}, 6.28 \%$ found C, $32.51 \% ; \mathrm{H}, 1.76 \%$; N, $6.20 \%$.

\subsection{Fluorescence Assays}

ThT $\left(50 \mu \mathrm{M}, \lambda_{\text {exc: }}=440 \mathrm{~nm}, \lambda_{\text {emis }}=481 \mathrm{~nm}\right)$ fluorescence assays were carried out at $25{ }^{\circ} \mathrm{C}$ employing a peptide concentration of $100 \mu \mathrm{M}$ in $10 \mathrm{mM}$ phosphate buffer at $\mathrm{pH}=7.4$, at indicated ratios of $\mathrm{Pt}$ (II) complexes. To compare different effects of $\mathrm{Pt}$ complexes to peptides alone, correctly, analyzed solutions contained DMSO at $2 \%(v / v)$. Spectra were recorded with a Jasco FP 8300 spectrofluorometer (JASCO, Tokyo, Japan) in a 1cm cuvette under magnetic stirring. Spectra were recorded every $15 \mathrm{~min}$ in indicated time, assays were performed in duplicates, and reported intensities are averaged values.

\subsection{UV/Vis Spectroscopy}

$\mathrm{UV} /$ Vis titration of different $\mathrm{Pt}(\mathrm{II})$ complexes with $\mathrm{A} \beta_{21-40}$ were carried out employing a Nanodrop 200 c spectrophotometer (Thermo Scientific, Milan, Italy). To a fixed concentration of the $\mathrm{Pt}(\mathrm{II})$ complexes $(20 \mu \mathrm{M})$, were added increasing amounts of $\mathrm{A} \beta_{21-40}$ of $2.0 \mu \mathrm{L}$ of peptide stock solutions $(500 \mu \mathrm{M})$ in water, kept at $0{ }^{\circ} \mathrm{C}$. Ratios reached were 1:6 complex: $A \beta_{21-40}$ for Pt-terpy and Pt-phen and 1:7.2 for Pt-bpy. Each spectrum was registered (220-400 $\mathrm{nm}$ ) upon the addition of the peptide, after a stirring time of $2 \mathrm{~min}$. $\mathrm{EC}_{50}$ value was derived from non-linear regression of the data employing log [inhibitor] vs. response and “dose-response stimulation equation" of GraphPad program [39].

\subsection{ESI-MS Analysis}

Solutions of $\mathrm{A} \beta_{21-40}$ at a concentration of $50 \mu \mathrm{M}$ in $15 \mathrm{mM}$ AMAC (Ammonium acetate) buffer $\mathrm{pH}=7.0$, at 1:5 ratios with $\mathrm{Pt}(\mathrm{II})$ complexes were incubated at two different times ( 0 and $24 \mathrm{~h}$ ) and then analyzed by Q-ToF Premier (Waters, Milliford, MA, USA) mass spectrometer. The analyses were done by direct injection at $10 \mu \mathrm{L} / \mathrm{min}$ and the source parameters were set as $3 \mathrm{kV}$ for capillary voltage and $42 \mathrm{kV}$ for cone voltage. The acquisition range was spanned from 900 to $2500 \mathrm{~m} / \mathrm{z}$ and the raw data were processed with MassLynx 4.1 software (Waters, Milliford, MA, USA).

\subsection{Spectroscopy}

CD spectra of $A \beta_{21-40}(100 \mu \mathrm{M}, 10 \mathrm{mM}$ phosphate buffer), with 1:1 and 1:5 ratios with $\mathrm{Pt}$ (II) terpy complex were registered at indicated times on a Jasco J-815 spectropolarimeter (JASCO, Tokyo, Japan), in a $0.1 \mathrm{~cm}$ cuvette. Deconvolutions of CD spectra were obtained by BESTSEL software (http:/ / bestsel.elte.hu/, accessed on 20 February 2021) [40].

\subsection{Cellular Assays}

\subsubsection{Cell Proliferation Assay}

Human neuroblastoma SH-SY5Y cell line was grown in DMEM (GIBCO, Paisley, UK) supplemented with $2 \mathrm{mM}$ L-glutamine, $50 \mathrm{ng} / \mathrm{mL}$ streptomycin, 50 units $/ \mathrm{mL}$ penicillin and $10 \%$ heat-inactivated fetal bovine serum (FBS) in a humidified atmosphere $\left(5 \% \mathrm{CO}_{2}\right.$ at $37^{\circ} \mathrm{C}$ ). Cells were detached with $0.25 \%$ trypsin (Sigma-Aldrich, Milan, Italy) at $70-80 \%$ of confluence.

\subsubsection{Sulforhodamine B (SRB) Assay}

To perform SRB assays, cells were seeded in triplicates in 96-well plates at a density of 8000 cells /well and left to adhere for $24 \mathrm{~h}$. $A \beta_{21-40}$ alone and $A \beta_{21-40}+$ Pt-terpy at 1:5 
ratio (after $0,2,24 \mathrm{~h}$ of stirring) were added to the culture in triplicates. After $24 \mathrm{~h}$, cells were fixed with $50 \% v / v$ trichloroacetic acid (for $2 \mathrm{~h}$ at $4{ }^{\circ} \mathrm{C}$ ) and then washed with water. Plates were dried overnight and then cells were stained with $0.4 \% w / v$ SRB in $1 \% v / v$ acetic acid at room temperature for $30 \mathrm{~min}$ on a shaker, and after washed with $1 \%$ acetic acid, to allow the removal the unbound dye [41]. They were resuspended with TRIS- $\mathrm{HCl}$ $10 \mathrm{mM}$, pH 7.4 and absorbance was measured at $495 \mathrm{~nm}$ employing a Glomax ${ }^{\circledR}$ Discover Microplate Reader (Promega, Madison, WI, USA).

Supplementary Materials: The following are available online at https:/ / www.mdpi.com/1422-006 7/22/6/3015/s1, Figure S1: ESI-MS spectra of mutA $\beta_{21-40}$ at 0 and $24 \mathrm{~h}$ of incubation in the absence and in the presence of Pt-terpy, Figure S2: Absorption spectra of Pt-phen, Pt-bpy and Pt-terpy upon the addition of increasing volume of solvents, Figure S3: Overlay of CD spectra of mutA $\beta_{21-40}$ in the absence and in the presence of Pt-terpy, Table S1: Deconvolution of CD spectra reported in Figure 5 at indicated times and ratios $\beta_{21-40}$ : Pt-terpy.

Author Contributions: D.M. designed the concept and supervised the experiments. S.L.M., D.F., I.D.B., I.I., F.N., A.M.M. and M.M. performed the experimental work. E.G. and M.R. synthesized and characterized the metal complexes. M.M., M.R. and D.M. wrote the manuscript. All authors have read and agreed to the published version of the manuscript.

Funding: This work was partially supported by POR CAMPANIA FESR 2014/2020 “Combattere la resistenza tumorale: piattaforma integrata multidisciplinare per un approccio tecnologico innovativo alle oncoterapie-Campania Oncoterapie" (Project N. B61G18000470007).

Data Availability Statement: The data presented in this study are available on request from the corresponding author.

Acknowledgments: Sara La Manna was supported by the AIRC fellowship for Italy, the authors thank Consorzio Interuniversitario di Ricerca in Chimica dei Metalli nei Sistemi Biologici (C.I.R.C.M.S.B.).

Conflicts of Interest: The authors declare no conflict of interest.

\section{References}

1. Shoghi-Jadid, K.; Small, G.W.; Agdeppa, E.D.; Kepe, V.; Ercoli, L.M.; Siddarth, P.; Read, S.; Satyamurthy, N.; Petric, A.; Huang, S.-C. Localization of neurofibrillary tangles and beta-amyloid plaques in the brains of living patients with Alzheimer disease. Am. J. Geriatr. Psychiatry 2002, 10, 24-35. [CrossRef]

2. Ke, P.C.; Zhou, R.; Serpell, L.C.; Riek, R.; Knowles, T.P.J.; Lashuel, H.A.; Gazit, E.; Hamley, I.W.; Davis, T.P.; Fandrich, M.; et al. Half a century of amyloids: Past, present and future. Chem. Soc. Rev. 2020, 49, 5473-5509. [CrossRef]

3. Mjos, K.D.; Orvig, C. Metallodrugs in medicinal inorganic chemistry. Chem. Rev. 2014, 114, 4540-4563. [CrossRef]

4. Derrick, J.S.; Lee, J.; Lee, S.J.; Kim, Y.; Nam, E.; Tak, H.; Kang, J.; Lee, M.; Kim, S.H.; Park, K.; et al. Mechanistic Insights into Tunable Metal-Mediated Hydrolysis of Amyloid-beta Peptides. J. Am. Chem. Soc. 2017, 139, 2234-2244. [CrossRef]

5. Son, G.; Lee, B.I.; Chung, Y.J.; Park, C.B. Light-triggered dissociation of self-assembled beta-amyloid aggregates into small, nontoxic fragments by ruthenium (II) complex. Acta Biomater. 2018, 67, 147-155. [CrossRef]

6. Suh, J.M.; Kim, G.; Kang, J.; Lim, M.H. Strategies Employing Transition Metal Complexes To Modulate Amyloid-beta Aggregation. Inorg. Chem. 2019, 58, 8-17. [CrossRef]

7. Hayne, D.J.; Lim, S.; Donnelly, P.S. Metal complexes designed to bind to amyloid-beta for the diagnosis and treatment of Alzheimer's disease. Chem. Soc. Rev. 2014, 43, 6701-6715. [CrossRef]

8. Storr, T.; Gomes, L.M.; Bataglioli, J.C.; Jussila, A.J.; Smith, J.R.; Walsby, C.J. Modification of AB Peptide Aggregation via Covalent Binding of a Series of Ru (III) Complexes. Front. Chem. 2019, 7, 838.

9. Florio, D.; Malfitano, A.M.; Di Somma, S.; Mugge, C.; Weigand, W.; Ferraro, G.; Iacobucci, I.; Monti, M.; Morelli, G.; Merlino, A.; et al. Platinum(II) O,S Complexes Inhibit the Aggregation of Amyloid Model Systems. Int. J. Mol. Sci. 2019, 20, 829. [CrossRef]

10. Barnham, K.J.; Kenche, V.B.; Ciccotosto, G.D.; Smith, D.P.; Tew, D.J.; Liu, X.; Perez, K.; Cranston, G.A.; Johanssen, T.J.; Volitakis, I.; et al. Platinum-based inhibitors of amyloid-beta as therapeutic agents for Alzheimer's disease. Proc. Natl. Acad. Sci. USA 2008, 105, 6813-6818. [CrossRef] [PubMed]

11. Gomes, L.M.; Bataglioli, J.C.; Storr, T. Metal complexes that bind to the amyloid- $\beta$ peptide of relevance to Alzheimer's disease. Coord. Chem. Rev. 2020, 412, 213255. [CrossRef]

12. Strodel, B.; Coskuner-Weber, O. Transition metal ion interactions with disordered amyloid- $\beta$ peptides in the pathogenesis of alzheimer's disease: Insights from computational chemistry studies. J. Chem. Inf. Modeling 2019, 59, 1782-1805. [CrossRef] [PubMed] 
13. Streltsov, V.A.; Chandana Epa, V.; James, S.A.; Churches, Q.I.; Caine, J.M.; Kenche, V.B.; Barnham, K.J. Structural insights into the interaction of platinum-based inhibitors with the Alzheimer's disease amyloid-beta peptide. Chem. Commun. (Camb.) 2013, 49, 11364-11366. [CrossRef] [PubMed]

14. Ma, G.; Huang, F.; Pu, X.; Jia, L.; Jiang, T.; Li, L.; Liu, Y. Identification of [PtCl2(phen)] binding modes in amyloid-beta peptide and the mechanism of aggregation inhibition. Chemistry 2011, 17, 11657-11666. [CrossRef] [PubMed]

15. Ma, G.; Wang, E.; Wei, H.; Wei, K.; Zhu, P.; Liu, Y. PtCl2(phen) disrupts the metal ions binding to amyloid-beta peptide. Metallomics 2013, 5, 879-887. [CrossRef] [PubMed]

16. Sasaki, I.; Bijani, C.; Ladeira, S.; Bourdon, V.; Faller, P.; Hureau, C. Interference of a new cyclometallated Pt compound with Cu binding to amyloid-beta peptide. Dalton Trans. 2012, 41, 6404-6407. [CrossRef]

17. Collin, F.; Sasaki, I.; Eury, H.; Faller, P.; Hureau, C. Pt (II) compounds interplay with Cu (II) and Zn (II) coordination to the amyloid- $\beta$ peptide has metal specific consequences on deleterious processes associated to Alzheimer's disease. Chem. Commun. 2013, 49, 2130-2132. [CrossRef]

18. Law, A.S.; Lee, L.C.; Yeung, M.C.; Lo, K.K.; Yam, V.W. Amyloid Protein-Induced Supramolecular Self-Assembly of Water-Soluble Platinum(II) Complexes: A Luminescence Assay for Amyloid Fibrillation Detection and Inhibitor Screening. J. Am. Chem. Soc. 2019, 141, 18570-18577. [CrossRef]

19. Babu, E.; Bhuvaneswari, J.; Rajakumar, K.; Sathish, V.; Thanasekaran, P. Non-conventional photoactive transition metal complexes that mediated sensing and inhibition of amyloidogenic aggregates. Coord. Chem. Rev. 2021, 428, 213612. [CrossRef]

20. La Manna, S.; Scognamiglio, P.L.; Roviello, V.; Borbone, F.; Florio, D.; Di Natale, C.; Bigi, A.; Cecchi, C.; Cascella, R.; Giannini, C.; et al. The acute myeloid leukemia-associated Nucleophosmin 1 gene mutations dictate amyloidogenicity of the C-terminal domain. FEBS J. 2019, 286, 2311-2328. [CrossRef]

21. De Santis, A.; La Manna, S.; Krauss, I.R.; Malfitano, A.M.; Novellino, E.; Federici, L.; De Cola, A.; Di Matteo, A.; D’Errico, G.; Marasco, D. Nucleophosmin-1 regions associated with acute myeloid leukemia interact differently with lipid membranes. Biochim. Biophys. Acta (BBA)-Gen. Subj. 2018, 1862, 967-978. [CrossRef]

22. Di Natale, C.; La Manna, S.; Avitabile, C.; Florio, D.; Morelli, G.; Netti, P.A.; Marasco, D. Engineered beta-hairpin scaffolds from human prion protein regions: Structural and functional investigations of aggregates. Bioorg. Chem. 2020, 96, 103594. [CrossRef]

23. Di Natale, C.; Florio, D.; Di Somma, S.; Di Matteo, A.; Federici, L.; Netti, P.A.; Morelli, G.; Malfitano, A.M.; Marasco, D. Proteostasis unbalance of nucleophosmin 1 in Acute Myeloid Leukemia: An aggregomic perspective. Int. J. Biol. Macromol. 2020, 164, 3501-3507. [CrossRef]

24. Di Natale, C.; La Manna, S.; Malfitano, A.M.; Di Somma, S.; Florio, D.; Scognamiglio, P.L.; Novellino, E.; Netti, P.A.; Marasco, D. Structural insights into amyloid structures of the C-terminal region of nucleophosmin 1 in type A mutation of acute myeloid leukemia. Biochim. Biophys. Acta (BBA)-Proteins Proteom. 2019, 1867, 637-644. [CrossRef]

25. Scognamiglio, P.L.; Di Natale, C.; Leone, M.; Cascella, R.; Cecchi, C.; Lirussi, L.; Antoniali, G.; Riccardi, D.; Morelli, G.; Tell, G. Destabilisation, aggregation, toxicity and cytosolic mislocalisation of nucleophosmin regions associated with acute myeloid leukemia. Oncotarget 2016, 7, 59129. [CrossRef] [PubMed]

26. Florio, D.; Iacobucci, I.; Ferraro, G.; Mansour, A.M.; Morelli, G.; Monti, M.; Merlino, A.; Marasco, D. Role of the Metal Center in the Modulation of the Aggregation Process of Amyloid Model Systems by Square Planar Complexes Bearing 2-(2'pyridyl)benzimidazole Ligands. Pharmaceuticals 2019, 12, 154. [CrossRef]

27. Florio, D.; Cuomo, M.; Iacobucci, I.; Ferraro, G.; Mansour, A.M.; Monti, M.; Merlino, A.; Marasco, D. Modulation of Amyloidogenic Peptide Aggregation by Photoactivatable CO-Releasing Ruthenium(II) Complexes. Pharmaceuticals 2020, 13, 171. [CrossRef]

28. Marshall, K.E.; Vadukul, D.M.; Dahal, L.; Theisen, A.; Fowler, M.W.; Al-Hilaly, Y.; Ford, L.; Kemenes, G.; Day, I.J.; Staras, K.; et al. A critical role for the self-assembly of Amyloid-beta1-42 in neurodegeneration. Sci. Rep. 2016, 6, 30182. [CrossRef]

29. Di Natale, C.; Scognamiglio, P.L.; Cascella, R.; Cecchi, C.; Russo, A.; Leone, M.; Penco, A.; Relini, A.; Federici, L.; Di Matteo, A.; et al. Nucleophosmin contains amyloidogenic regions that are able to form toxic aggregates under physiological conditions. FASEB J. 2015, 29, 3689-3701. [CrossRef]

30. Skiba, J.; Bernas, T.; Trzybinski, D.; Wozniak, K.; Ferraro, G.; Marasco, D.; Merlino, A.; Shafikov, M.Z.; Czerwieniec, R.; Kowalski, K. Mitochondria Targeting with Luminescent Rhenium(I) Complexes. Molecules 2017, 22, 809. [CrossRef]

31. McInnes, E.L.; Farley, R.; Rowlands, C.; Welch, A.; Yellowlees, L. On the electronic structure of [Pt (4, 4'-X 2-bipy) Cl 2] 0/-/2-: An electrochemical and spectroscopic (UV/Vis, EPR, ENDOR) study. J. Chem. Soc. Dalton Trans. 1999, 4203-4208. [CrossRef]

32. Jin, V.X.; Ranford, J.D. Complexes of platinum (II) or palladium (II) with 1, 10-phenanthroline and amino acids. Inorg. Chim. Acta 2000, 304, 38-44. [CrossRef]

33. Arena, G.; Calogero, G.; Campagna, S.; Monsù Scolaro, L.; Ricevuto, V.; Romeo, R. Synthesis, characterization, absorption spectra, and luminescence properties of organometallic platinum (II) terpyridine complexes. Inorg. Chem. 1998, 37, 2763-2769. [CrossRef]

34. Mannini, B.; Habchi, J.; Chia, S.; Ruggeri, F.S.; Perni, M.; Knowles, T.P.; Dobson, C.M.; Vendruscolo, M. Stabilization and characterization of cytotoxic A $\beta 40$ oligomers isolated from an aggregation reaction in the presence of zinc ions. ACS Chem. Neurosci. 2018, 9, 2959-2971. [CrossRef] [PubMed]

35. Silveira, J.R.; Raymond, G.J.; Hughson, A.G.; Race, R.E.; Sim, V.L.; Hayes, S.F.; Caughey, B. The most infectious prion protein particles. Nature 2005, 437, 257-261. [CrossRef] [PubMed]

36. Wang, X.H.; Wang, X.Y.; Zhang, C.L.; Jiao, Y.; Guo, Z.J. Inhibitory action of macrocyclic platiniferous chelators on metal-induced A beta aggregation. Chem. Sci. 2012, 3, 1304-1312. [CrossRef] 
37. Gabano, E.; Perin, E.; Fielden, C.; Platts, J.A.; Gallina, A.; Rangone, B.; Ravera, M. How to obtain Pt (iv) complexes suitable for conjugation to nanovectors from the oxidation of [ $\mathrm{PtCl}$ (terpyridine)]+. Dalton Trans. 2017, 46, 10246-10254. [CrossRef] [PubMed]

38. Gabano, E.; Gama, S.; Mendes, F.; Fregonese, F.; Paulo, A.; Ravera, M. Application of microwave-assisted heating to the synthesis of Pt (II) complexes. Inorg. Chim. Acta 2015, 437, 16-19. [CrossRef]

39. Doti, N.; Scognamiglio, P.L.; Madonna, S.; Scarponi, C.; Ruvo, M.; Perretta, G.; Albanesi, C.; Marasco, D. New mimetic peptides of the kinase-inhibitory region (KIR) of SOCS1 through focused peptide libraries. Biochem. J. 2012, 443, 231-240. [CrossRef]

40. Micsonai, A.; Wien, F.; Kernya, L.; Lee, Y.H.; Goto, Y.; Refregiers, M.; Kardos, J. Accurate secondary structure prediction and fold recognition for circular dichroism spectroscopy. Proc. Natl. Acad. Sci. USA 2015, 112, E3095-E3103. [CrossRef] [PubMed]

41. Malfitano, A.M.; Laezza, C.; Pisanti, S.; Gazzerro, P.; Bifulco, M. Rimonabant (SR141716) exerts anti-proliferative and immunomodulatory effects in human peripheral blood mononuclear cells. Br. J. Pharm. 2008, 153, 1003-1010. [CrossRef] [PubMed] 